\title{
Immunoelectron microscopy of acute graft versus host disease of the skin after allogeneic bone marrow transplantation
}

\author{
M Takata, T Imai, T Hirone
}

\begin{abstract}
Aims-To clarify the pathological mechanisms of acute cutaneous graft versus host disease (GvHD) following allogeneic bone marrow transplantation.

Methods-Skin biopsy specimens from five patients were examined by immunoelectron microscopy. A panel of monoclonal antibodies against $T$ cell and natural killer cell subpopulations was used, including anti-CD4, - CD8, - CD16b, -CD56, - CD57, and -TCR $\delta 1$ antibodies.

Results-All the specimens contained CD8 + cells, CD4 + cells, and CD56 + cells infiltrating the epidermis. Cells stained with anti-CD16b, - CD57, or -TCR $\delta 1$ were very sparse or absent. Most of the CD8 + cells in the epidermis displayed morphological features of activated cytotoxic $T$ lymphocytes and apposition of such cells to degenerating keratinocytes was shown. CD4+ cells outnumbered CD8 + cells in the epidermis in all five cases. Noticeable intercellular as well as intracellular oedema of keratinocytes was observed at the site of prominent CD4 + cell infiltration, suggesting that these also have a role as actual effector cells by secreting cytotoxic cytokines. CD56 + cells infiltrating the epidermis did not exhibit the characteristic ultrastructural morphology of the natural killer cells thus far examined, and their lineage remained uncertain.

Conclusions-These data provide direct evidence that CD8 + cytotoxic $\mathbf{T}$ cells attack keratinocytes, and further suggest that CD4+ cells as well as CD56 + cells participate in the cellular pathogenesis of acute cutaneous GvHD.
\end{abstract}

$(\mathcal{F}$ Clin Pathol 1993;46:801-805)

Table 1 Clinical characterisation of patients with acute GvHD after allogeneic bone marrow transplantation

\begin{tabular}{llllll}
\hline $\begin{array}{l}\text { Case } \\
\text { No }\end{array}$ & $\begin{array}{l}\text { Age/sex } \\
\text { (years) }\end{array}$ & $\begin{array}{l}\text { Original } \\
\text { disease }\end{array}$ & $\begin{array}{l}\text { Onset of } \\
\text { skin rash }\end{array}$ & $\begin{array}{l}\text { Time of } \\
\text { biopsyt }\end{array}$ & $\begin{array}{l}\text { Histological } \\
\text { gradef }\end{array}$ \\
\hline 1 & 22/M & CML & 30 & 32 & II \\
2 & $17 / M$ & AMoL & 19 & 21 & II \\
3 & $27 / M$ & CML & 20 & 24 & III \\
4 & $17 / F$ & ALL & 24 & 27 & III \\
5 & 23/M & CML & 31 & 36 & III
\end{tabular}

${ }^{\star} \mathrm{CML}$, chronic myelocytic leukaemia; AMoL, acute monocytic leukaemia; ALL, acute lymphocytic leukaemia.

Days after bone marrow transplantation.

fAccording to the classification of Lerner $e t a l^{13}$.

Acute graft versus host disease (GvHD) is a major complication of allogeneic bone marrow transplantation. Although donor T lymphocytes are thought to have an important role in the development of acute GvHD, the precise nature of the effector cells and the mechanisms of tissue injury in target organs remain unknown. ${ }^{12}$

Skin is one of the major target organs in acute GvHD, and the pathological mechanisms involved have been intensively investigated. ${ }^{3}$ Early histopathological studies have shown epidermotropic migration of lymphocytes and hyalinised necrosis of keratinocytes, often associated with adjacent lymphocytesthat is, satellite cell necrosis-as characteristic features of acute cutaneous $\mathrm{GvHD}$, leading to the concept of the "aggressor lymphocyte" as a primary effector cell..$^{45}$ Recent immunohistological analyses have shown that most infiltrating cells in the affected skin are $\mathrm{CD} 3+\mathrm{T}$ cells, with a predominance of CD8 + suppressor/cytotoxic $T$ cells $s^{6-9}$ or CD4 + helper/inducer $\mathrm{T}$ cells. ${ }^{10-12}$ The surface phenotype and the functional characteristics of effector cells, however, are still unclear.

The purpose of this study was to investigate the phenotype and ultrastructural morphology of migrating mononuclear cells in the epidermis which may actually cause epithelial injury, and to clarify the cellular pathogenesis involved in acute cutaneous GvHD.

\section{Methods}

Five patients who developed acute GvHD after allogeneic bone marrow transplantation from HLA-identical sibling donors were included in this study. The clinical characterisation of these five cases is summarised in table 1. All the patients received cyclosporin in association with short-term methotrexate for the prophylaxis of the GvHD. Skin biopsy specimens were taken from the various sites within four days of the onset of skin rash. According to the histopathological grading proposed by Lerner $e t a l,^{13}$ two patients (cases 1 and 2) had grade II histological changes and three (cases 3, 4, and 5) had grade III changes. None of the patients developed extracutaneous manifestations.

The skin tissue from each biopsy specimen was fixed in freshly prepared periodate-lysineparaformaldehyde (PLP), embedded in OCT compound (Miles Scientific, Elkhart, Indiana), and frozen in liquid nitrogen. Cryosections $(6 \mu \mathrm{m})$ were stained using the 
Table 2 Monoclonal antibodies for immunohistochemistry

\begin{tabular}{|c|c|c|}
\hline Antibody & $\begin{array}{l}\text { Cluster of } \\
\text { differentiation }\end{array}$ & $\begin{array}{l}\text { Predominant } \\
\text { reactivity }\end{array}$ \\
\hline $\begin{array}{l}\text { Leu } 3 a+3 b \\
\text { Leu } 2 a \\
\text { Leu } 11 b \\
\text { Leu } 19\end{array}$ & $\begin{array}{l}\text { CD4 } \\
\text { CD8 } \\
\text { CD16b } \\
\text { CD56 }\end{array}$ & $\begin{array}{l}\text { Helper/inducer T cells } \\
\text { Suppressor/cytotoxic T cells } \\
\text { Natural killer cells, granulocytes } \\
\text { Natural killer cells, activated T } \\
\text { and B cells }\end{array}$ \\
\hline $\begin{array}{l}\text { Leu } 7 \\
\operatorname{TCR} \delta 1\end{array}$ & CD57 & $\begin{array}{l}\text { Natural killer cells, some CD8 + } \\
\mathrm{T} \text { cells } \\
\gamma \delta \mathrm{T} \text { cells }\end{array}$ \\
\hline
\end{tabular}

^Leu series monoclonal antibodies were purchased from Becton Dickinson Immunocytometry Systems, Sunnyvale, California, and TCR $\delta 1$ antibody from T Cell Science, Cambridge, Massachusetts.

Table 3 Antigenic phenotype of infiltrating cells in the epidermis

\begin{tabular}{llrl}
\hline \multirow{4}{*}{ Case No } & \multicolumn{4}{l}{ Number of cells $/ \mathrm{mm}^{*}$} \\
\cline { 2 - 4 } & CD4 & $C D 8$ & CD56 \\
\hline 1 & $28 \cdot 2$ & $6 \cdot 4$ & $\mathrm{NE}$ \\
2 & $50 \cdot 0$ & $30 \cdot 0$ & $\mathrm{NE}$ \\
3 & $28 \cdot 3$ & 14.0 & $35 \cdot 7$ \\
4 & $33 \cdot 3$ & 3.6 & $4 \cdot 0$ \\
5 & $34 \cdot 3$ & 13.3 & $17 \cdot 8$ \\
\hline
\end{tabular}

^Actual number of positively labelled cells per linear millimetre length of epidermis. NE, not examined.

biotin-streptavidin method, as described before. ${ }^{14}$ Briefly, the sections were first reacted overnight at $4^{\circ} \mathrm{C}$ with various primary monoclonal antibodies listed in table 2, followed by the sequential incubations with biotinylated goat antimouse immunoglobulins and peroxidase-conjugated streptavidin (Biogenex Laboratories, San Ramon, California). After having been refixed with $1 \%$ glutaraldehyde solution the sections were

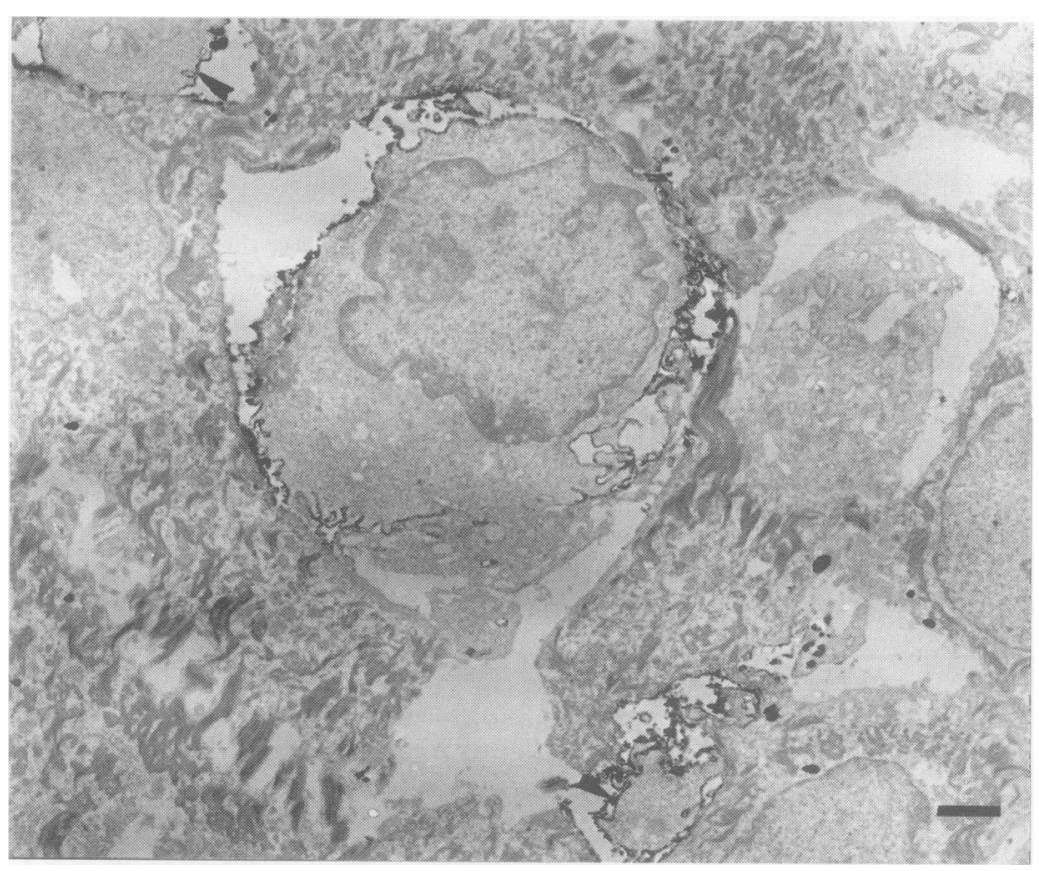

Figure $1 A C D 8+$ lymphocyte infiltrating in the epidermis which has a euchromatic nucleus, abundant cytoplasm, and cell surface microvilli-like projections. Cytoplasmic projections of other CD8+ cells (arrowheads) are also seen in close contact with adjacent keratinocytes (case 2; bar $=1 \mu \mathrm{m}$ ). treated with $0.02 \%$ diaminobenzidine (DAB) solution containing $0.01 \%$ hydrogen peroxide. They were then postfixed with $2 \%$ osmium tetroxide, dehydrated, and embedded in Epoxy resin. Semithin sections $(1 \mu \mathrm{m})$ were cut, counterstained with methylene blue, and observed by light microscopy. Finally, ultrathin sections were prepared from the appropriate Epon blocks, stained with 1\% uranyl acetate, and examined with an electron microscope.

\section{Results}

LIGHT MICROSCOPY

The profiles of the proportion of cells labelled with various monoclonal antibodies were similar among all five cases studied. All had $\mathrm{CD} 4+, \mathrm{CD} 8+$, and CD56 + cells as main cellular infiltrates. CD57+ cells and TCR $\delta 1+$ cells were either absent or detected only occasionally within the dermal perivascular infiltrates. None of the specimens contained $\mathrm{CD} 16 \mathrm{~b}+$ cells. Table 3 gives the actual number of $\mathrm{CD} 4+, \mathrm{CD} 8+$, as well as CD56+ cells observed in the epidermis. CD4 + cells outnumbered CD8 + cells in all cases and the CD4:CD8 ratio ranged from $1 \cdot 7$ to $9 \cdot 2$. CD56 + cells constituted a significant proportion of the epidermal infiltrates in three of the cases examined. CD56 was the most predominant phenotype in case 3 . In the remaining two cases (cases 4 and 5) the numbers of CD56+ cells slightly exceeded those of CD8 + cells. Further electron microscopic observations were carried out in the specimens stained with CD4, CD8, and CD56 antibodies.

\section{ELECTRON MICROSCOPY}

Most of the CD8 + lymphocytes found in the epidermis had an eccentrically located euchromatic nucleus and an abundant cytoplasm at one pole of the cell. These CD8+ lymphocytes possessed microvilli-like projections on the cell surface, which were often observed congruent with the cell membrane of adjacent keratinocytes (fig 1). Such contacts between CD8 + lymphocytes and keratinocytes were found in all the cases. Target keratinocytes exhibited various degrees of cytoplasmic damage. Figure 2 shows a CD8 + lymphocyte that was found apposed to a basal layer keratinocyte undergoing apparent filamentous degeneration. The lymphocyte showed polarity with an eccentrically located nucleus and abundant cytoplasm facing the degenerating keratinocyte. The cytoplasm contained many cell organelles such as mitochondria and multivesicular bodies.

All the specimens contained numerous CD4 + cells in the epidermis. Most such CD4 + cells were lymphocytes, but some macrophages with indented nuclei and cytoplasmic autophagosomes were weakly stained with CD4 antibody. The ultrastructural morphology of the CD4 + lymphocytes was variable, and many of them had elongated cytoplasm which contained fewer cell organelles than the CD8 + lymphocytes. In 


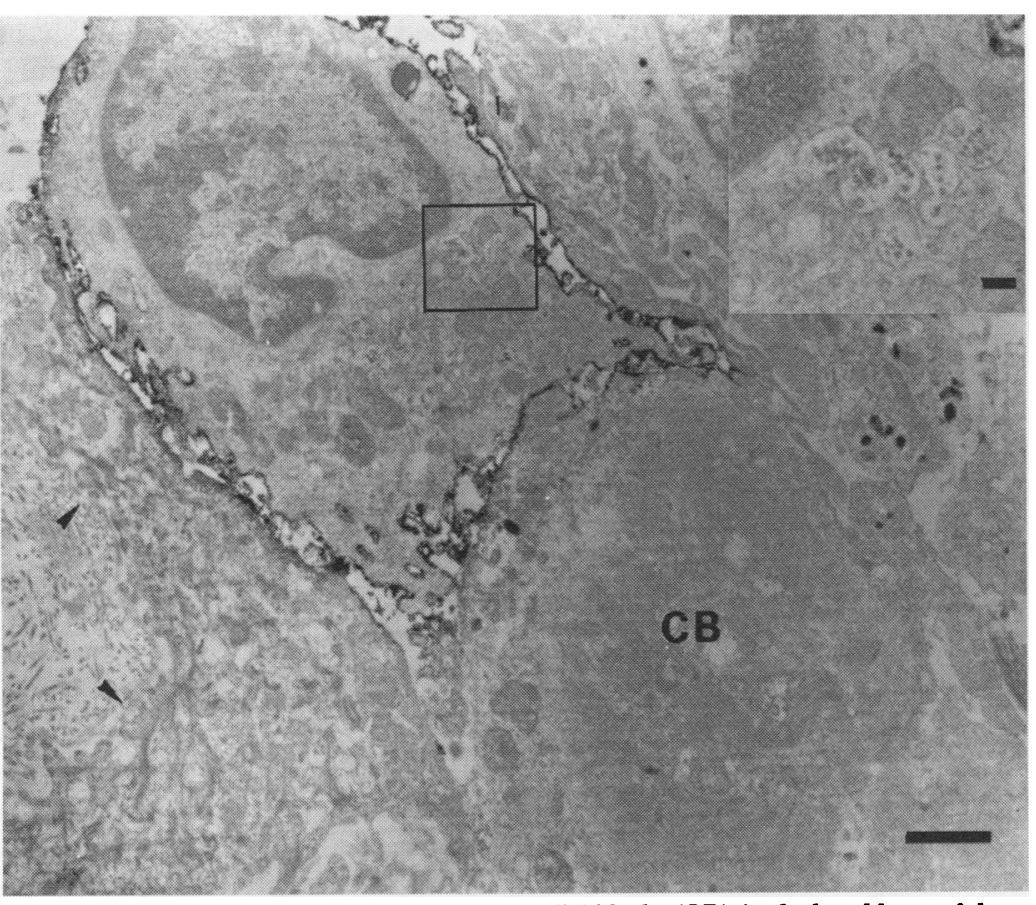

Figure $2 A C D 8+$ lymphocyte apposed to a colloid body $(C B)$ in the basal layer of the epidermis. The lymphocyte has an eccentrically located nucleus and a cytoplasm containing many cell organelles such as mitochondria and multivesicular bodies. The enclosed area is magnified in the inset. Arrowheads indicate the basal lamina (case 3; bar = $1 \mu \mathrm{m}$; inset: bar $=0.1 \mu \mathrm{m}$ ). contrast to $\mathrm{CD} 8+$ cells, any contiguity between $\mathrm{CD} 4+$ lymphocytes with keratinocytes was rare. At the site of prominent infiltration of CD4 + lymphocytes, however, the intercellular connection of keratinocytes was disrupted, leading to the complete disapperance of desmosomes from the cell surface. Some keratinocytes showed intracytoplasmic oedema and vacuolisation (fig 3 ).

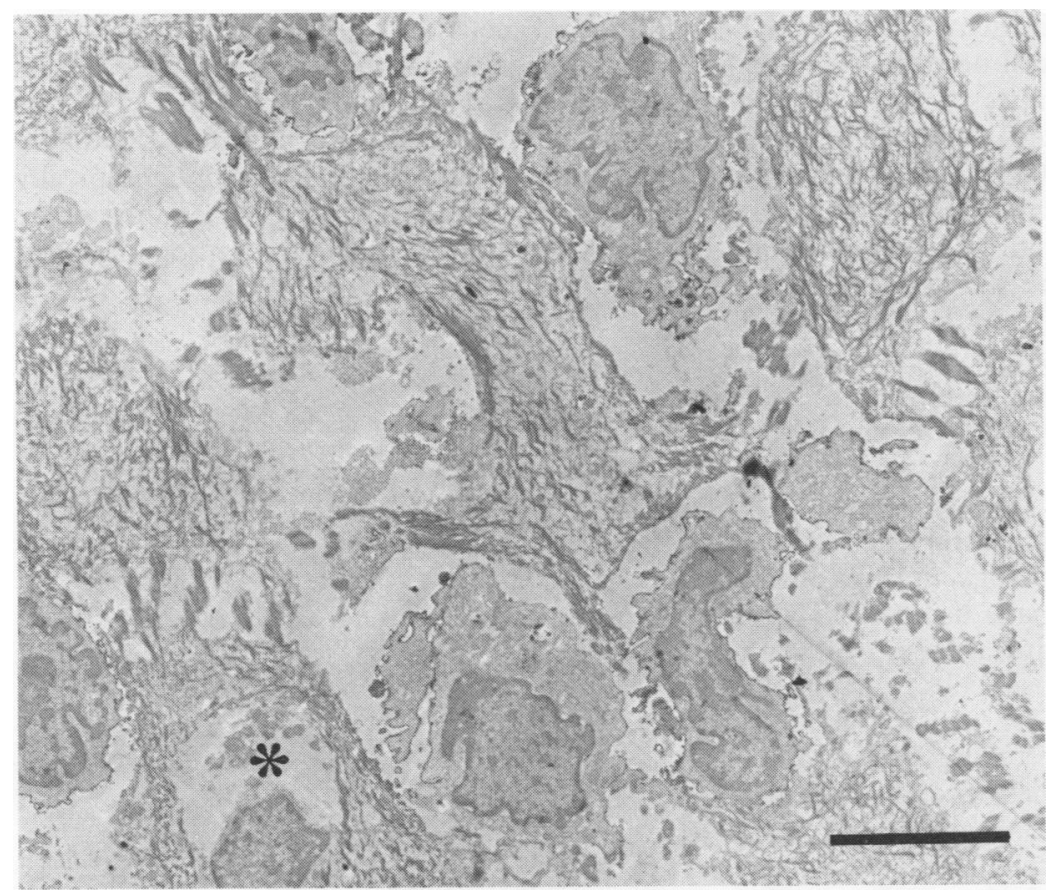

Figure 3 A site of numerous CD4+ cell infiltration in the epidermis. Note pronounced intercellular as well as intracellular oedema of keratinocytes (asterisk) with partial or complete loss of desmosomes from the cell surface (case 1); bar $=5 \mu \mathrm{m}$.
In three cases CD56+ cells were mainly distributed in the intercellular spaces of the lower epidermis. Most of the CD56+ cells possessed a centrally located nucleus and a small rim of cytoplasm with a relatively high nuclear:cytoplasmic ratio (fig 4). Some of them had cytoplasmic projections, but contiguity between $\mathrm{CD} 56+$ cells and adjacent keratinocytes was rarely seen. Although multivesicular bodies were common, electron dense granules could not be identified in the cytoplasm of CD56+ cells thus far examined.

\section{Discussion}

The ultrastructural observations of the affected skin in acute GvHD disclosed prominent migration of lymphocytes in the epidermis, disruption of intercellular connections of keratinocytes, and a close association between migrating lymphocytes and degenerating keratinocytes..$^{515}$ Subsequent immunohistological studies of acute GvHD showed infiltration of $\mathrm{CD} 8+$ suppressor/cytotoxic $\mathrm{T}$ cells into the epidermis. $^{610}$ These ultrastructural and immunohistochemical findings strongly suggested that migrating lymphocytes in the epidermis are cytotoxic $T$ cells which mediate epidermal cell injury.

In the present study we have shown that most of the intraepidermal CD8 + cells exhibit morphological features of stimulated cytotoxic $T$ lymphocytes ${ }^{16}{ }^{17}$-that is, they had cell surface microvilli, euchromatic nuclei, and cell organelle-rich cytoplasms containing multivesicular bodies. Furthermore, the apposition of a CD8 + lymphocyte to a keratinocyte undergoing filamentous degeneration was shown. Our observations therefore provide more direct evidence that intraepidermal $\mathrm{CD} 8+$ cells are activated cytotoxic $\mathrm{T}$ cells and cause epidermal cell necrosis by direct cell to cell contacts.

Although most of the previous immunohistological studies of acute cutaneous GvHD have identified $\mathrm{CD} 4+$ helper/inducer $\mathrm{T}$ cells within the dermal infiltrate, ${ }^{7-12}$ only two studies have described the infiltration of the epidermis by $\mathrm{CD} 4+$ cells. Sloane et $a l^{10}$ observed CD4 $+\mathrm{T}$ cells in the epidermis in five out of eight cases, but precluded the participation of these cells in the pathogenesis of GvHD, because there was no correlation between the intensity of the epidermal changes and the presence of epidermal CD4 + cells. Beschorner et al, ${ }^{18}$ who examined the epithelial HLA-DR antigen expression and surface phenotype of infiltrating lymphocytes, noted a mixed infiltrate containing more $\mathrm{CD} 4+$ cells than $\mathrm{CD} 8+$ cells in the epidermis in specimens with positive epithelial HLA-DR expression. We also showed numerous CD4 + cells infiltrating the epidermis on the electron microscopic level. CD4 + lymphocytes were mostly found in the widened intercellular spaces in the epidermis without apposition to adjacent keratinocytes. The role of these intraepidermal CD4 + cells in the pathogenesis of acute GvHD is still 


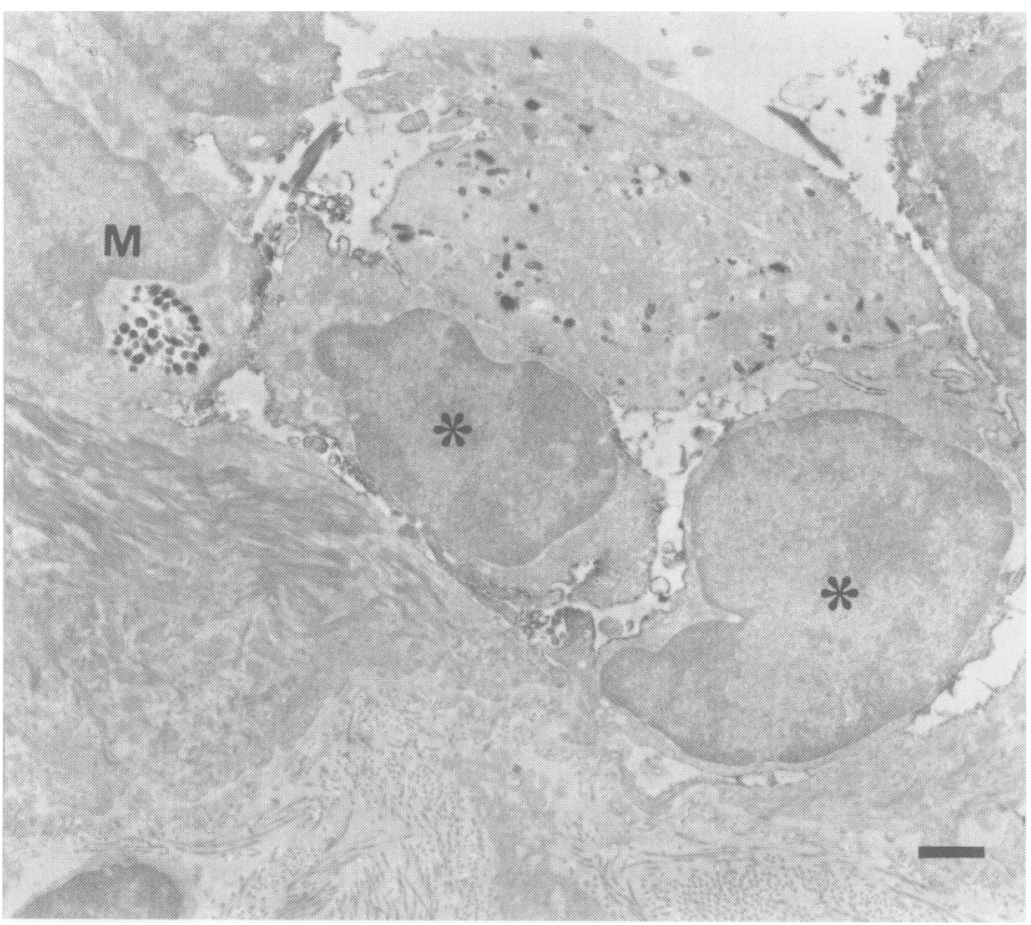

Figure 4 Two CD56+ cells infiltrating in the basal layer of the epidermis ( $\left.{ }^{\star}\right) . C D 56$ lymphocytes and macrophages (M) are also present (case 5; bar = $1 \mu \mathrm{m}$ ).

unclear. In animal experiments, however, Shiohara et $a l^{19}$ and Murphy et $a l^{20}$ showed that a certain type of helper $\mathrm{T}$ cell clone or purified donor CD4 $+\mathrm{T}$ cell inoculated into the appropriate recipients induces histological changes consistent with cutaneous GvHD, and have indicated that CD4 $+\mathrm{T}$ cells act as actual effector cells of acute GvHD. These authors suggested that cytotoxic cytokines, such as tumour necrosis factor- $\alpha$ and interferon- $\gamma$ released from $\mathrm{CD} 4+$ helper $\mathrm{T}$ cells are responsible for the epithelial injury. It is therefore possible that CD4 $+\mathrm{T}$ cells found in the epidermis of human acute GvHD could cause epidermal cell necrosis by secreting these cytotoxic mediators.

Participation of natural killer cells in the pathogenesis of acute GvHD is a matter of controversy. Dokhelar et $a l^{21}$ reported a strong association between high peripheral blood natural killer activity and the development of GvHD during the first month after a transplantation, and suggested that natural killer cells may be involved in the development of acute GvHD. In experimental models of murine acute GvHD, infiltrating mononuclear cells in the skin had phenotypic and morphological features of natural killer cells. ${ }^{22} 23$ In spite of these findings immunohistochemical studies in humans using CD57 and CD16b antibodies as natural killer cell markers did not detect those cells in the skin lesions of acute GvHD. ${ }^{72}$ Very recently, however, Acevedo et al, ${ }^{24}$ using several different monoclonal antibodies recognising a natural killer cell subset, have detected a substantial number of cells displaying a natural killer cell associated phenotype, such as CD56 and Kp43 antigens in the skin infiltrates of acute GvHD. In the present study we also identified a considerable number of CD56 + cells migrating into the epidermis. Ultrastructurally, however, we were not able to show the presence of cytoplasmic electrondense granules in these CD56 + cells which are characteristic of natural killer cells and are closely associated with cytotoxic activity. ${ }^{25}$ Furthermore, close contact between CD56+ cells and adjacent keratinocytes was rare. Therefore, we have no evidence that these CD56 cells are natural killer cells and act as actual effector cells. As it has been recently shown that the expression of CD56 antigen is not restricted to natural killer cells, but is seen on $\mathrm{CD} 4+$ or $\mathrm{CD} 8+$ interleukin-2 dependent $T$ cell clones maintained on long term cultures, ${ }^{26}$ the possibility remains that the CD56 + cells identified in the skin lesion of acute GvHD are activated $T$ cells rather than natural killer cells. Further ultrastructural studies as well as investigations using double immunohistochemical staining with $\mathrm{T}$ cell markers are needed to confirm the lineage of the CD56 + cells.

The $\mathrm{CD} 3+\gamma \delta \mathrm{T}$ cells are distributed mainly in the epithelia and have natural killer cell-like non-major histocompatibility complex-restricted cytotoxic activity. ${ }^{27}$ Ferrara et $a^{23}$ showed that cells showing high natural killer activity are important effector cells mediating tissue injury in their experimental model of murine GvHD. They proposed that CD $3+\gamma \delta \mathrm{T}$ cells may be the primary effector cells. This seems unlikely in human GvHD, however, because in concordance with the recent study of Norton et al ${ }^{8}$ very few TCR $\delta 1+$ cells were detected in the skin of acute GvHD.

This immunoelectron microscopic study has shown the direct cytotoxic activity of CD8 + lymphocytes against epidermal keratinocytes in acute GvHD of the skin. The pathogenetic participation of CD4 + helper/ inducer $T$ cells and of CD56 + cells is also apparent, although their precise role remains uncertain. CD4 + lymphocytes seem to act as actual effector cells. Furthermore, cytokine mediated interaction of these phenotypically different subsets of lymphocytes might be important in the cellular pathogenesis of acute GvHD.

1 Tsoi MS. Immunological mechanisms of graft-versus-host disease in man. Tranplantation 1982;33:459-64.

2 Snover DC. Acute and chronic graft-versus-host disease: Histopathological evidence for two distinct pathogenetic mechanisms. Hum Pathol 1984;15:202-5.

3 Breathnach SM. Current understanding of the aetiology and clinical implications of cutaneous oraft-versus-host disease. Br $₹$ Dermatol 1986;114:139-43.

4 Sale GE, Lerner KG, Barker EA, Shulman HM, Thomas ED. The skin biopsy in the diagnosis of acute graft-versus-host disease in man. Am $\mathcal{F}$ Pathol 1977;89:621-36.

5 Grogan TM, Odom RB, Burgess JH. Graft-vs-host reaction. Arch Dermatol 1977;113:806-12.

6 Lampert IA, Janossay G, Suitters AJ, et al. Immunological analysis of the skin in graft versus host disease. Clin Exp analysis of the skin in graft

7 Kay VN, Neumann PM, Kersey J, et al. Identity of immune cells in graft-versus-host-disease in the skin Analysis using monoclonal antibodies by indirect immunofluorescence. Am $\mathcal{F}$ Pathol 1984;116:436-40.

8 Lever R, Turbitt M, Mackie R, et al. A prospective study of the histological changes in the skin in patients receiving bone marrow transplants. Br $\mathcal{F}$ Dermatol 1986;114 161-70. 
9 Girolomoni G, Pincelli C, Zambruno G, et al. Immunohistochemistry of cutaneous graft-versus-host disease after allogeneic bone marrow transplantation. $f$ after allogeneic bone
Dermatol 1991;18:314-23.

10 Sloane JP, Thomas JA, Imrie SF, Easton DF, Powles RL. Morphological and immunohistological changes in the skin in allogeneic bone marrow recipients. $F$ Clin Pathol 1984;37:919-30.

11 Dreno B, Milpied N, Harousseau JL, et al. Cutaneous immunological studies in diagnosis of acute graftversus-host disease. Br $\mathcal{F}$ Dermatol 1986;114:7-15

12 Paller AS, Nelson A, Steffen L, Gottschalk L, Kaizer H. T-lymphocyte subsets in the lesional skin of allogeneic and autologous bone marrow transplant patients. Arch Dermatol 1988;124:1795-801.

13 Lerner KG, Kao GF, Storb R, Bucker CD, Clift RA Thomas ED. Histopathology of graft-versus-host reaction (GvHR) in human recipients of marrow from tion (GvHR) in human recipients of marrow from HLA-match

14 Takata $M$, Hirone T, Matsumura H. $\beta_{2}$ microglobulin expression in normal melanocytes, nevocellular nevi, and malignant melanomas. F Invest Dermatol 1989, 92:243s-7s

15 Rozman C, Mascaro JM, Granena A, Palou J, Feliu E, Castel T. Ultrastructural findings in acute and chronic graft-vs-host reaction of the skin. F Cut Pathol 1980; 7:354-63.

16 Matter A, Simpson E. The differentiation of cytotoxic T lymphocytes in vitro. An ultrastructural study. Cell lymphocytes in vitro. An

17 Poulsen PB, Nielsen LH. Cytological events in allo-stimulated lymphocytes triggered by exposure to stimulatory alloantigens. I. Changes in cell size, the mitochondrial areal density and numerical density of the endoplasmic reticulum and the Golgi apparatus. Acta Pathol Microbiol Scand (Sec C) 1979;87:131-40.

18 Beschorner WE, Farmer ER, Saral R, Stirling WL, Santos GW. Epithelial class II antigen expression in cutaneous graft-versus-host disease. Transplantation 1987;44:237-43.

19 Shiohara $T$, Narimatsu $H$, Nagashima $M$. Induction of cutaneous graft-versus-host disease by allo- or self-Iareactive helper $T$ cells in mice. Transplantation 1987 ; 43:692-8.

20 Murphy GF, Whitaker D, Sprent J, Korngold R Characterization of target injury of murine acute graftversus-host disease directed to multiple minor histoCD8 + effector cells. Am $\mathcal{F}$ Pathol 1991;138:983-90.

21 Dokhelar MC, Wiels J, Lipinski M, et al. Natural killer cell activity in human bone marrow recipients. Early reappearance of peripheral natural killer activity in graftversus-host disease. Transplantation 1981;31:61-5.

22 Guillen FJ, Ferrara J, Hancock WW, et al. Acute cutaneous graft-versus-host disease to minor histocompatibiity antigens in a murine model. Evidence that large granular lymphocytes are effector cells in the immune granular lymphocytes are effector cell

23 Ferrara ЛM, Guillen FJ, van Dijken PJ, Marion A Murphy GF, Burakoff SJ. Evidence that large granular lymphocytes of donor origin mediate acute graft-versushost disease. Transplantation 1989;47:50-4

24 Acevedo A, Aramburu J, Lopez J, Fernandez-Herrera J, Fernandez-Ranada JM, Lopez-Botet M. Identification of natural killer (NK) cells in lesions of human cutaneous graft-versus-host disease: Expression of a novel NK-associated surface antigen (Kp43) in mononuclear infiltrates. $\mathcal{F}$ Invest Dermatol 1991;97:659-66.

25 Carpen O, Virtanen I, Saksela E. Ultrastructure of human natural killer cells: Nature of the cytolytic contacts in relation to cellular secretion. $f$ Immunol 1982;128: relation

26 Lanier LL, Le AM, Ding A, et al. Expression of Leu-19 (NKH-1) antigen on IL 2-dependent cytotoxic and non-cytotoxic $T$ cell lines. $\mathcal{F}$ Immunol 1987;138: 2019-23

27 Janeway CA, Jones B, Hayday A. Specificity and function of $T$ cells bearing $\gamma / \delta$ receptors. Immunol Today 1988 9:73-6.

28 Norton J, Al-Saffar N, Sloane JP. An immunohistological study of $\gamma / \delta$ lymphocytes in human cutaneous graft-versus-host disease. Bone Marrow Transplant 1991;7:205-8. 